\section{DiscoverSys \\ Published by DiscoverSys \\ Anemia as a risk factor of postpartum hemorrhage at dr. R. Soedjono Hospital, Selong, East Lombok}

\author{
Ernawati, ${ }^{1}$ Komang Ayu Kartika Sari, ${ }^{2}$ I Nyoman Gede Budiana, ${ }^{3}$ Luh Seri Ani ${ }^{2 *}$
}

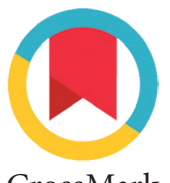

CrossMark

\title{
ABSTRACT
}

Background and purpose: Globally, maternal mortality rate due to labor complications remains high, with postpartum hemorrhage as the most common cause. Studies on the risk factors of postpartum hemorrhage have been widely published, however, its association with maternal anemia is inconsistent. This study aims to explore anemia as a risk factor for postpartum hemorrhage.

Methods: A case control study was carried out with 69 women who experienced postpartum hemorrhage as cases and 207 women who had given birth but did not experience hemorrhage as controls. Cases and controls were taken from medical records at the dr. R. Soedjono Hospital, Selong, East Lombok District, West Nusa Tenggara. Cases were selected by systematic random sampling from 147 mothers who experienced postpartum hemorrhage during 2017. Controls were selected in the same way from 2,855 mothers who did not experience postpartum hemorrhage. Cases and controls were matched for birth weight of infants and maternal employment. Data were obtained by medical record extraction in May 2018 consisting of information on hemoglobin concentration, parity, age at pregnancy, birthing method, gestational age, birth spacing and length of labor. Data analysis was performed using logistic regression to determine the adjusted odds ratio (AOR) of anemia.

Results: Characteristics of cases and controls were found to be similar in terms of infant birth weight, maternal occupation, parity, gestational age and length of delivery but statistically different by maternal age at pregnancy and birth spacing. Analysis with logistic regression showed thatanemia during pregnancy with hemoglobin concentration $\leq 10 \mathrm{gr} / \mathrm{dL}$ was a significant risk factor for postpartum hemorrhage with $A O R=16.32$ (95\%Cl: 7.69-34.64). Delivery through caesarean section (SC) or oxytocin drip was also found to significantly reduce the risk of postpartum hemorrhage $(\mathrm{AOR}=0.03 ; 95 \% \mathrm{Cl}: 0.01-0.13)$.

Conclusion: Anemia during pregnancy with hemoglobin concentration $\leq 10 \mathrm{gr} / \mathrm{dL}$ was found to be a risk factor for postpartum hemorrhage. Prevention and control of anemia in pregnant women need to be enhanced to prevent postpartum hemorrhage.
${ }^{1}$ East Lombok Hamzar Health Institute,

${ }^{2}$ Department of Public Health and Preventive Medicine, Faculty of Medicine, Udayana University, ${ }^{3}$ Department of Obstetrics and Gynecology, Sanglah General Hospital
*Correspondence to: Luh Seri Ani, Department of Public Health and Preventive Medicine, Faculty of Medicine, Udayana University luhseriani@yahoo.com

Keywords: postpartum hemorrhage, anemia, East Lombok

Cite This Article: Ernawati, Sari, K.A.K., Budiana, I.N.G., Ani, L.S. 2018. Anemia as a risk factor of postpartum hemorrhage at dr. R. Soedjono Hospital, Selong, East Lombok. Public Health and Preventive Medicine Archive 6(2): 124-127. D0I:10.15562/phpma.v6i2.151

\section{INTRODUCTION}

Maternal mortality ratio (MMR) in Indonesia in 2007 was reported to be 228 per 100,000 live births, and in 2012 amounted to 359 per 100,000 live births. ${ }^{1}$ Globally, the direct causes of maternal death during pregnancy and childbirth were bleeding, infection after childbirth, preeclampsia/eclampsia, complications during labor and unsafe abortion. The most common direct cause is postpartum hemorrhage which defined as bleeding $>500 \mathrm{ml}$ after vaginal delivery or $1000 \mathrm{ml}$ after caesarian delivery. ${ }^{2,3}$ Bleeding can occur during the first 24 hours after delivery (primary post-partum hemorrhage) or $>24$ hours to 6 weeks (secondary post-partum hemorrhage). ${ }^{4}$

In Indonesia, direct causes of maternal mortality are postpartum hemorrhage (30.3\%), hypertension during pregnancy $(27.1 \%)$, infection $(7.3 \%)$, prolonged labor $(1.8 \%)$, and abortion $(1.6 \%){ }^{5}$ Deaths due to postpartum hemorrhage mostly occurs within 24 hours after delivery. ${ }^{5}$ Postpartum hemorrhage at the dr. R. Soedjono Hospital, Selong,
East Lombok District in 2015, 2016, 2017 was reported to be $5.5 \%, 5.0 \%$ and $3.0 \%$, respectively. ${ }^{6}$

Previous studies have shown that risk factors for postpartum hemorrhage included anemia, maternal age during pregnancy, parity, gestational age, type and length of labor. ${ }^{7-12}$ Those studies showed inconsistent results on the association of anemia, maternal age during pregnancy, parity and length of labor with postpartum hemorrhage. The purpose of this study was to determine anemia as a risk factor for postpartum hemorrhage.

\section{METHODS}

A case control study was carried out among 276 pregnant women consisted of 69 women who experienced postpartum hemorrhage as cases and 207 women who had given birth but did not experience hemorrhage as controls (1:3). Number of samples was determined with the significance level of $95 \%$, power of $80 \%$, proportion of anemia among women without postpartum hemorrhage 
Table 1 Characteristics of cases and controls

\begin{tabular}{lccc}
\hline Characteristics & $\begin{array}{c}\text { Cases } \\
\mathbf{n}(\%)\end{array}$ & $\begin{array}{c}\text { Controls } \\
\mathbf{n}(\%)\end{array}$ & $\mathbf{p}$ \\
\hline $\begin{array}{l}\text { Birth weight of infants } \\
\geq 2500 \mathrm{gr}\end{array}$ & $62(89.86)$ & $190(91.79)$ & 0.62 \\
$<2500 \mathrm{gr}$ & $7(10.14)$ & $17(8.21)$ & \\
Maternal employment & & & \\
Housewives & $55(79.71)$ & $159(76.81)$ & 0.81 \\
Entrepreneur & $5(7.25)$ & $12(5.80)$ & \\
Farmer & $5(7.25)$ & $21(10.14)$ & \\
Teacher & $1(1.45)$ & $8(3.86)$ & \\
Laborer & $1(1.45)$ & $3(1.45)$ & \\
Student & $1(1.45)$ & $1(0.48)$ & \\
Others & $2(2.90)$ & $6(2.90)$ & \\
\hline
\end{tabular}

Table 2 Crude OR of variables associated with postpartum hemorrhage

\begin{tabular}{|c|c|c|c|c|c|}
\hline Variables & $\begin{array}{l}\text { Cases } \\
\text { n (\%) }\end{array}$ & $\begin{array}{c}\text { Controls } \\
\text { n (\%) }\end{array}$ & $\begin{array}{c}\text { Crude } \\
\text { OR }\end{array}$ & $95 \% \mathrm{Cl}$ & $\mathbf{p}$ \\
\hline \multicolumn{6}{|l|}{ Parity } \\
\hline $\begin{array}{l}1 \text { child or } \geq 4 \\
\text { children }\end{array}$ & $31(44.93)$ & $109(52.66)$ & 0.73 & $0.40-1.31$ & 0.27 \\
\hline 2-3 children & $38(55.07)$ & $98(47.34)$ & & & \\
\hline \multicolumn{6}{|l|}{ Age at pregnancy } \\
\hline$<20$ or $>35$ years & $26(37.68)$ & $50(24.15)$ & 1.89 & $1.01-3.52$ & 0.03 \\
\hline 20-35 years & $43(62.32)$ & $157(75.85)$ & & & \\
\hline \multicolumn{6}{|l|}{ Type of delivery } \\
\hline $\begin{array}{l}\text { Caesarean or } \\
\text { oxytocin drip }\end{array}$ & $3(4.35)$ & $98(47.34)$ & 0.05 & $0.01-0.16$ & $<0.01$ \\
\hline Spontaneous & $66(95.65)$ & $109(52.66)$ & & & \\
\hline \multicolumn{6}{|l|}{ Term of pregnancy } \\
\hline$<37$ weeks & $2(2.90)$ & $4(1.93)$ & 1.51 & $0.13-10.84$ & 0.63 \\
\hline$\geq 37$ weeks & $67(97.10)$ & $203(98.07)$ & & & \\
\hline \multicolumn{6}{|l|}{ Birth spacing } \\
\hline$<2$ or $>5$ years & $36(75.0)$ & $60(47.62)$ & 3.3 & $1.50-7.58$ & $<0.01$ \\
\hline $2-5$ years & $12(25.0)$ & $66(52.38)$ & & & \\
\hline \multicolumn{6}{|l|}{ Length of labour } \\
\hline$>12$ hours & $30(43.48)$ & $98(47.34)$ & 0.85 & $0.47-1.53$ & 0.58 \\
\hline$\leq 12$ hours & $39(56.52)$ & $109(52.66)$ & & & \\
\hline \multicolumn{6}{|l|}{ Hb concentration } \\
\hline $\mathrm{Hb}<11 \mathrm{gr} / \mathrm{dL}$ & $\begin{array}{c}152 \\
(73.43)\end{array}$ & $51(73.91)$ & 0.95 & $1.47-7.53$ & 0.76 \\
\hline $\mathrm{Hb} \geq 11 \mathrm{gr} / \mathrm{dL}$ & $55(26.57)$ & $18(26.06)$ & & & \\
\hline \multicolumn{6}{|l|}{ Hb concentration } \\
\hline $\mathrm{Hb} \leq 10 \mathrm{gr} / \mathrm{dL}$ & $54(78.26)$ & $43(20.77)$ & 13.73 & $6.78-28.52$ & $<0.01$ \\
\hline $\mathrm{Hb}>10 \mathrm{gr} / \mathrm{dL}$ & $15(21.74)$ & $164(79.23)$ & & & \\
\hline
\end{tabular}

NB: Birth spacing analysed only for women reporting parity $\geq 2$ of $26 \%$ and anticipated odd ratio of $2.0 . .^{7}$ Cases and controls were taken from medical records at the dr. R. Soedjono Hospital, Selong, East Lombok District, West Nusa Tenggara using a data extraction form. Cases were selected by systematic random sampling from 147 mothers who experienced postpartum hemorrhage during 2017. Controls were selected in the same way from 2,855 mothers who did not experience postpartum hemorrhage that year. Cases and controls were matched for the birth weight of infants and maternal employment. Data on the exposures were obtained by medical record extraction in May 2018 consisting of hemoglobin concentration, parity, age at pregnancy, gestational age, type and length of labor. Multivariate analysis was performed with logistic regression to determine the adjusted odd ratio (AOR) of anemia.

This study has been approved by the Ethics Committee of the Faculty of Medicine, the University of Mataram on May 15, 2018.

\section{RESULTS}

Table 1 presents the distribution of cases and controls by birth weight of infants and maternal employment. It was shown that there were no significant differences on cases and controls by birth weight of infants $(\mathrm{p}=0.622)$ and maternal employment ( $\mathrm{p}=0.808)$.

Table 2 shows the crude odd ratios of parity, age at pregnancy, type of delivery, gestational age, birth spacing and hemoglobin $(\mathrm{Hb})$ concentration. All variables with $\mathrm{p}<0.25$ were analyzed using logistic regression. Table 3 shows that $\mathrm{Hb}$ concentration during pregnancy $\leq 10 \quad \mathrm{~g} / \mathrm{dL} \quad(\mathrm{AOR}=16.32$; 95\%CI: 7.69-3.64) is the significant risk factor for postpartum hemorrhage, however it is not significantly associated with $\mathrm{Hb}$ concentration during pregnancy $\leq 11 \mathrm{~g} / \mathrm{dL}(\mathrm{OR}=0.95 ; 95 \% \mathrm{CI}$ : 1.47-7.53). Delivery by caesarean section (SC) or oxytocin drip was found to significantly reduce the risk of postpartum hemorrhage $(\mathrm{AOR}=0.03$; 95\%CI: 0.01-0.13).

\section{DISCUSSION}

This study shows that anemia during pregnancy with $\mathrm{Hb}$ concentration $\leq 10 \mathrm{~g} / \mathrm{dL}$ increased the risk of postpartum hemorrhage. However, $\mathrm{Hb}$ concentration of $<11 \mathrm{gr} / \mathrm{dL}$ was not found to be a significant risk factor for postpartum hemorrhage in this study. Anemia with $\mathrm{Hb}$ concentration $\leq 10 \mathrm{~g} / \mathrm{dL}$ was also found to be a risk factor of postpartum hemorrhage in several other studies., ${ }^{713}$ A casecontrol study conducted among women who gave 


\begin{tabular}{|c|c|c|c|}
\hline Variables & AOR & $95 \% \mathrm{Cl}$ & $\mathbf{p}$ \\
\hline \multicolumn{4}{|l|}{ Type of delivery } \\
\hline Spontaneous & 1.00 & & \\
\hline Caesarean or oxytocin drip & 0.03 & $0.01-0.13$ & $<0.01$ \\
\hline \multicolumn{4}{|l|}{ Birth spacing } \\
\hline $2-5$ years & 1.00 & & \\
\hline$<2$ years and $>5$ years & 2.40 & $0.99-5.82$ & 0.05 \\
\hline \multicolumn{4}{|l|}{ Hb concentration } \\
\hline $\mathrm{Hb}>10 \mathrm{gr} / \mathrm{dL}$ & 1.00 & & \\
\hline $\mathrm{Hb} \leq 10 \mathrm{gr} / \mathrm{dL}$ & 16.32 & $7.69-34.64$ & $<0.01$ \\
\hline
\end{tabular}

birth in a hospital in Norway showed that anemia with $\mathrm{Hb}$ concentration $\leq 9 \mathrm{gr} / \mathrm{dL}$ increased the risk of postpartum hemorrhage by 4.27 times. ${ }^{14}$ World Health Organization determined $\mathrm{Hb}$ concentration of $<11 \mathrm{gr} / \mathrm{dL}$ as anemia in pregnant women, with $\mathrm{Hb}$ concentration of 10-10.9 $\mathrm{gr} / \mathrm{dL}$ determined as mild anemia, $\mathrm{Hb}$ of 7-9.9 gr/dL as moderate anemia and $\mathrm{Hb}<7.0 \mathrm{gr} / \mathrm{dL}$ as severe anemia. ${ }^{15}$ Our study and some other studies indicated that anemia is a risk factor of postpartum hemorrhage particularly among mothers experiencing anemia from mild to severe levels.

Our study also found that the type of delivery, particularly delivery with caesarean section or oxytocin drip, can reduce the risk of postpartum hemorrhage. This may be due to the fact that most cases in our study were referred to the hospital due to delivery complications including hemorrhage, while the controls were mostly patients who gave birth at the hospital and when there was a problem during delivery then caesarean section or oxytocin drip was conducted. These make caesarean section and oxytocin drip appear to reduce the risk of postpartum hemorrhage in this study. This result is contrary to the results of a study conducted in Norway which found that delivery by caesarean section and induced labor was a risk factor for postpartum haemorrhage. ${ }^{14}$ Case definition in our study did not limit the severity of postpartum hemorrhage, while the study conducted in Norway only used cases with severe hemorrhage. In addition, it is likely due to the different cases and controls selection.

Limitations in our study include the use of hospital data as the source of cases and controls, also the inclusion of referral patients with hemorrhage. Thus the cases and controls in this study do not represent cases and controls in the population. In addition, the information used in this study was only sourced from hospital medical records so that the variables studied are very limited and highly dependent on the accuracy of the data obtained in the medical records. This study was also carried out only in one hospital in one district so that the results of this study could not be generalized to a wider area or population.

\section{CONCLUSION}

Risk factor for postpartum hemorrhage is anemia during pregnancy with $\mathrm{Hb}$ level $\leq 10 \mathrm{~g} / \mathrm{dl}$ but it is not significantly associated with $\mathrm{Hb}$ level $<11 \mathrm{~g} / \mathrm{dl}$. Delivery by caesarean section and/or oxytocin drip was found to reduce the risk of postpartum hemorrhage. While parity, maternal age, gestational age, birth spacing and length of labor were not found to be risk factors for postpartum hemorrhage. The implication of this study include the need to improve efforts to prevent and overcome anemia in women before pregnancy and during pregnancy.

\section{ACKNOWLEDGEMENT}

We would like to thank the Director of the dr. R. Soedjono Hospital, Selong, East Lombok District and staff who have supported the data collection of this study.

\section{REFERENCES}

1. National Demographic and Family Planning Board. Survei Demografi dan Kesehatan Indonesia 2012 [The 2012 Indonesia Demography and Health Survey]. Jakarta. 2013.

2. World Health Organization. Trends in maternal mortality: 1990 to 2015. 2015; World Health Organization. Geneva.

3. Oxorn H. Ilmu Kebidanan Patologi dan Fisiologi Persalinan [Pathology Obstetrics and Labor Physiology]. Yayasan Esentia Medika. Yogyakarta. 2010.

4. Alarm International Program. Postpartum hemorrhage. Fourth edition of the alarm international program. 2000. Canada.

5. Ministry of Health of Indonesia. Profil Kesehatan Indonesia [Indonesia Health Profile]. 2015. Jakarta.

6. dr. R. Soedjono Hospital. Laporan angka dan penyebab kematian ibu [Report on maternal mortality rate and the causes]. Selong. 2017.

7. Lestari GE. Analisis hubungan anemia dengan perdarahan postpartum di RSUD Jendral Ahmad Yani Kota Metro tahun 2013 [Analysis on the association of anemia with postpartum hemorrhage at Metro City Jendral Ahmad Yani Hospital 2013]. Jurnal Kesehatan Metro Sai Wawai. 2014. 7(2): 65-75.

8. Frass KA. Postpartum hemorrhage is related to the hemoglobin levels at labor: observational study. Alexandria Journal of Medicine. 2015. 51(4): 3337.

9. Kramer MS, Dahhou M, Vallerand D, Liston R, Joseph KS. Risk factors for postpartum hemorrhage: Can we explain the recent temporal increase. Journal of Obstetrics and Gynaecology Canada. 2011. 33(8): 810-9.

10. Risnawati I, Hanung A. Dampak anemia kehamilan terhadap perdarahan post partum [The impact of anemia during preganncy on postpartum bleeding]. Jurnal Ilmu Keperawatan dan Kebidanan STIKES Muhammadiyah Kudus. 2015. 6(3): 57-67. 
11. Sheldon WR, Blum J, Vogel JP, Souza JP, Gülmezoglu AM, Winikoff B, et al. Postpartum haemorrhage management, risks, and maternal outcomes: findings from the World Health Organization Multicountry Survey on Maternal and Newborn Health. BJOG. 2014. 121: 5-13.

12. Friyandini F. Hubungan kejadian perdarahan postpartum dengan faktor risiko karakteristik ibu di RSUP dr. M. Djamil Padang [The association of postpartum hemorrhage with maternal characteristics as the risk factors at Padang dr. M. Djamil Hospital]. Jurnal Kesehatan Andalas. 2013; 4(3): $850-5$

13. Megasari M. Faktor-faktor yang berhubungan dengan kejadian perdarahan pasca persalinan di RSUD Arifin Achmad Provinsi Riau [Factors associated with postpartum hemorrhage at Riau Province Arifin Achmad Hospital]. Jurnal Kesehatan Komunitas Hang Tuah. 2013. 2(5):72-7.
14. Lili TN, Sandven I, Pedersen BS, Pettersen S, Al-Zirqi I, Rosemberg. Risk factors for severe postpartum hemorrhage: a case-control study. BMC Pregnancy Childbirth. 2017;17(1):1-9.

15. World Health Organization. Hemoglobin concentrations for the diagnosis of anaemia and assessment of severity. Vitamin and Mineral Nutrition Information System. 2011; World Health Organization. Geneva.

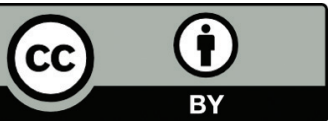

This work is licensed under a Creative Commons Attribution 